MaPan : Jurnal Matematika dan Pembelajaran

p-ISSN: 2354-6883 ; e-ISSN: 2581-172X

Volume 7 No 1, June 2019 (155-166)

DOI: https://doi.org/10.24252/mapan.2019v7n1a12

\title{
PENGARUH MODEL PROBLEM BASED LEARNING TERHADAP KEMAMPUAN PEMECAHAN MASALAH MATEMATIS DAN KEYAKINAN MATEMATIS SISWA
}

\author{
Helda Monica1), Nila Kesumawati2), Ety Septiati ${ }^{3)}$ \\ 1,2,3Program Studi Pendidikan Matematika, Universitas PGRI Palembang \\ 1,2,3J1. Jend. A. Yani Lr. Gotong Royong 9/10 Ulu Palembang \\ E-mail: heldamonica95@gmail.com ${ }^{1}$, nilakesumawati@yahoo.com ${ }^{2}$, \\ etyseptiati@univpgri_palembang.ac.id $\left.{ }^{3}\right)$
}

Submitted: 17-04-2018, Revised: 29-06-2019, Accepted: 29-06-2019

\begin{abstract}
Abstrak:
Penelitian ini bertujuan untuk mengetahui pengaruh model Problem Based Learning $(P B L)$ terhadap kemampuan pemecahan masalah matematis dan keyakinan matematis siswa SMP. Penelitian ini dilaksanakan di SMPN 6 Gelumbang Sumatera Selatan. Metode yang digunakan dalam penelitian ini adalah metode eksperimen Postest-Only Control Design. Sampel penelitian ini adalah 62 siswa. Instrumen yang di gunakan adalah tes kemampuan pemecahan masalah matematis dan angket keyakinan matematis. Teknik analisis data yang digunakan adalah uji t. Hasil penelitian menunjukkan bahwa ada pengaruh model Problem Based Learning (PBL) terhadap kemampuan pemecahan masalah matematis dan keyakinan siswa di SMPN 6 Gelumbang Sumatera Selatan.
\end{abstract}

Kata Kunci: Problem Based Learning, Pemecahan Masalah, Keyakinan Matematis

\section{THE INFLUENCE OF PROBLEM BASED LEARNING APPROACH TO THE ABILITY OF SOLVING MATHEMATICAL PROBLEMS AND BELIEF OF STUDENTS}

\begin{abstract}
:
This study aims to know whether there is influence of Problem Based Learning (PBL) approach to the ability of solving mathematical problem, mathematical belief of students of SMP. This study did at SMPN 6 Gelumbang, South Sumatera. The method used in this study is the Postest-Only Control Design experiment method. The sample in this study was 62 students. The instrument of this study was the ability of solving mathematical problem test and mathematical belief questionnaire. Data analysis technique used is t test. The result of the study was there is influence of Problem Based Learning (PBL) approach to the ability of solving mathematical problem the belief of students of students SMPN 6 Gelumbang, South Sumatera.
\end{abstract}

Keywords: Problem Based Learning, Problem Solving, Mathematical Belief 
How to Cite: Monica, H., Kesumawati, N., \& Septiati, E. (2019). Pengaruh model problem based learning terhadap kemampuan pemecahan masalah matematis dan keyakinan matematis siswa di SMPN 6 Gelumbang Sumatera Selatan. MaPan: Jurnal Matematika dan Pembelajaran, 7(1), 155-166.

\section{PENDAHULUAN}

Matematika merupakan salah satu bidang studi yang memiliki peranan penting dalam pendidikan (Dinandar, 2014). Dalam hal ini yang berperan aktif dalam pelaksanaan dan kegiatan kurikulum adalah guru dan siswa, maka interaksi antara guru dan siswa sangat diperlukan agar meningkatnya mutu pendidikan dan tercapainya tujuan pembelajaran yang ingin di dicapai. Cara mencapai tujuan tersebut antara lain dengan melakukan pembelajaran matematika di sekolah. Pembelajaran matematika diharapkan dapat mengembangkan kemampuan siswa dalam berpikir, sehingga kecerdasan yang diperoleh bukan hanya berdasarkan nilai akademis di sekolah, akan tetapi juga dalam kehidupan sehari-hari (Sari, 2014)

Matematika merupakan salah satu komponen dari serangkaian mata pelajaran yang mempunyai peranan penting dalam pendidikan (Sundayana, 2015: 2). Berikut ini diungkapkan tujuan pembelajaran matematika berdasarkan Permendiknas No. 22 Tahun 2006, yaitu: (1) memahami konsep matematika, menjelaskan keterkaitan antar konsep, dan mengaplikasikan konsep atau algoritma, secara luwes, akurat, efisien, dan tepat dalam pemecahan masalah; (2) menggunakan penalaran pada pola dan sifat, melakukan manipulasi matematika dalam membuat generalisasi, menyusun bukti, atau menjelaskan gagasan dan pernyataan matematika; (3) memecahkan masalah yang meliputi kemampuan memahami masalah, merancang model matematika, menyelesaikan model, dan menafsirkan solusi yang diperoleh; (4) mengomunikasikan gagasan dengan simbol, tabel, diagram, atau media lain untuk memperjelas keadaan atau masalah; (5) memiliki sikap menghargai kegunaan matematika dalam kehidupan, yaitu memiliki rasa ingin tahu, perhatian, dan minat dalam mempelajari matematika, serta sikap ulet dan percaya diri dalam pemecahan masalah. Berdasarkan lima tujuan yang telah dikemukakan, ini berarti bahwa matematika sangat diperlukan oleh setiap orang dalam kehidupan sehari-hari untuk membantu memecahkan permasalahan.

Menurut Tim Depdiknas (2006) pemecahan masalah merupakan kompetensi strategi yang ditunjukkan siswa dalam memahami, memilih model 
dan strategi pemecahan masalah, dan menyelesaikan model untuk menyelesaikan masalah (Shadiq, 2009). Sedangkan menurut Gunantara, Suarjana, \& Riastini, (2014) kemampuan pemecahan masalah merupakan kecakapan atau potensi yang dimiliki seseorang atau siswa dalam menyelesaikan permasalahan dan mengaplikasikan dalam kehidupan seharihari. Sejalan dengan pendapat di atas menurut Ayu, Nurrahmawati, \& Deswita (2016) kemampuan pemecahan masalah matematika meliputi kemampuan memahami masalah, ,merancang model matematika, menyelesaikan model dan menafsirkan solusi yang diperoleh.

Menurut Polya dalam Yulianti, Sukasno, \& Friansah (2016) kemampuan pemecahan sebagai satu usaha mencari jalan keluar dari suatu kesulitan guna mencapai satu tujuan yang tidak begitu mudah segera untuk dicapai. Oleh karena itu, pemecahan masalah merupakan satu usaha mencari jalan keluar dari suatu kesulitan guna mencapai suatu tujuan yang tidak mudah dicapai dengan menarik pengetahuan yang dimiliki melalui tindakan, tahap demi tahap secara sistematis yang akan membangun pemahaman matematis baru.

Berdasarkan kenyataan di atas, siswa kita akan membuat kesalahan jika diberikan soal non rutin. Itu berarti kemampuan pemecahan masalah siswa Indonesia masih kurang, padahal dalam pembelajaran matematika kemampuan pemecahan masalah sangat penting, sebagaimana dikemukakan oleh Gani dalam Kesumawati (2009) bahwa kemampuan pemecahan masalah sebagai jantungnya matematika. Kemampuan pemecahan masalah amatlah penting dalam matematika, yang dikemudian hari dapat diterapkan dalam bidang studi lain dan dalam kehidupan sehari-hari.

Oleh karena itu, kemampuan pemecahan masalah matematis bukan hanya sebagai tujuan dari pembelajaran matematika tetapi juga merupakan kegiatan yang penting dalam pembelajaran matematika, karena selain siswa mencoba memecahkan masalah dalam matematika, mereka juga termotivasi untuk bekerja dengan sungguh-sungguh untuk menyelesaikan permasalahan dalam matematika dengan baik.

Selain kemampuan pemecahan masalah matematis, terdapat aspek psikologi yang memberikan kontribusi terhadap keberhasilan siswa dalam menyelesaikan permasalahan matematika dengan baik. Aspek psikologi tersebut adalah keyakinan matematis siswa, yakni keyakinan (belief) siswa terhadap matematika mempengaruhi bagaimana ia "menyebut" pelajaran matematikanya. Keyakinan yang salah, seperti menganggap matematika pelajaran yang sulit, sangat abstrak, penuh rumus dan hanya bisa "dikuasai" 
oleh anak jenius, menjadikan banyak siswa yang cemas yang berlebihan dalam menghadapi pelajaran dan ulangan/ujian matematika (Widjajanti, 2009). Sedangkan menurut Sugiman (2009) keyakinan matematis adalah salah satu aspek yang paling penting dalam dimensi afektif. Menurut Goldin keyakinan matematika seseorang terbentuk dari sikap terhadap matematika yang dimilikinya dan selanjutnya keyakinan tersebut akan membentuk nilai matematika pada diri orang tersebut (Sugiman, 2009).

Menurut Sugiman (2010) keyakinan matematika merupakan struktur kognitif yang dimiliki seseorang berkenaan dengan pandangannya terhadap matematika. Demikian siswa yang memiliki keyakinan matematika tinggi akan menghargai dirinya dan memiliki kepercayaan diri yang baik sehingga menganggap pembelajaran matematika menyenangkan dan menimbulkan keberanian serta kemampuan dalam meningkatkan prestasi belajar.

Berdasarkan hasil wawancara dengan guru di SMPN 6 Gelumbang pembelajaran disekolah masih menggunakan pembelajaran konvensional yaitu guru hanya siap mentransfer ilmunya langsung kepada siswa, dengan kata lain guru yang aktif sedangkan siswa pasif dalam belajar. Materi pelajaran yang dirasakan oleh siswa masih bersifat abstrak, siswa hanya diberikan materi, contoh, dan soal tanpa harus siswa mengembangkan pengetahuannya sendiri akibatnya kurangnya kemampuan pemecahan masalah dalam menyelesaikan soal-soal matematika. Selain itu, ketika diminta untuk berpendapat atau disuruh maju ke depan (presentasi) siswa merasa takut dan ragu karena kurangnya keyakinan diri mereka terhadap dirinya sendiri akibatnya sulit mengemukakan pendapat dengan tepat dan jelas.

Dari beberapa hal di atas, dapat diketahui bahwa kemampuan pemecahan masalah matematis dan keyakinan matematis siswa masih tergolong rendah, sehingga menyebabkan hasil belajar matematika rendah. Untuk meningkatkan hasil belajar matematika siswa, peran guru sangat penting. Guru mempunyai tugas untuk memilih metode pembelajaran yang sesuai dengan materi yang disampaikan, sehingga berpeluang untuk mendorong siswa lebih aktif dalam memecahkan masalah dan keyakinan yang lebih baik dalam kehidupan sehari-sehari. Dari beberapa model pembelajaran salah satu model yang relevan untuk digunakan dalam penelitian ini yaitu model Problem Based Learning (PBL).

Guru dituntut dapat memilih model pembelajaran yang dapat memacu semangat siswa untuk secara aktif ikut terlibat dalam pengalaman belajarnya. Salah satu alternatif model pembelajaran yang mungkin dikembangkan 
keterampilan berpikir siswa (penalaran, komunikasi dan koneksi) dalam memecahkan masalah adalah pembelajaran Problem Based Learning (PBL) Menurut Hamruni Problem Based Learning (PBL) adalah suatu model pembelajaran yang dimulai dengan menyelesaikan suatu masalah, tetapi untuk menyelesaikan masalah itu peserta didik memerlukan pengetahuan baru untuk dapat menyelesaikannya (Suyadi, 2015: 129). Sejalan dengan pendapat diatas menurut Nurbaiti dalam Dinandar (2014) Problem based learning (PBL) merupakan suatu model pembelajaran yang menjadikan masalah sebagai titik awal dalam memulai pembelajaran dan dirancang sebagai pembelajaran yang menuntut siswa untuk memperoleh kemampuan menyelesaikan masalah, kemandirian dan memiliki skill pertisipasi yang baik guna mendapatkan suatu pengetahuan baru.

Menurut Gunantara et al., (2014) Problem Based Learning (PBL) adalah proses yang ditempuh oleh seseorang untuk menyelesaikan masalah yang dihadapinya sampai masalah itu tidak lagi menjadi masalah baginya. Sejalan dengan pendapat diatas menurut Gunantara et al., (2014) Problem Based Learning (PBL) adalah model pembelajaran yang melibatkan siswa dalam menyelesaikan masalah nyata.

Jadi dapat disimpulan bahwa metode Problem Based Learning (PBL) adalah salah satu metode pembelajaran yang mendorong siswa untuk lebih aktif dalam mengembangkan suatu kemampuan pemecahan masalah serta mampu berusaha mencari solusi dari permasalahan dunia nyata.

Berdasarkan uraian di atas, maka dilakukan penelitian yang bertujuan untuk mengetahui adakah pengaruh model problem based learning terhadap kemampuan pemecahan masalah matematis dan keyakinan siswa SMP di Kecamatan Gelumbang.

\section{METODE PENELITIAN}

Metode dalam penelitian ini menggunakan metode eksperimen dengan desain postest only control design. Populasi dalam penelitian ini adalah seluruh siswa kelas VII SMP Negeri 6 Gelumbang tahun ajaran 2017/2018 pada semester ganjil, berjumlah 94 siswa dengan ketentuan bahwa populasi dalam penelitian ini merupakan suatu populasi yang bersifat homogen, dalam arti tidak terdapat adanya kelas unggulan. Sampel dalam penelitian ini diambil dengan menggunakan teknik acak (random) yaitu cluster random sampling, ,maka diambil dua kelas kemudian kelas yang terpilih adalah kelas VII.A sebagai kelas 
eksperimen berjumlah 32 siswa dan kelas VII.B sebagai kelas kontrol berjumlah 30 siswa.

Teknik pengumpulan data yang digunakan dalam penelitian ini adalah tes dan angket. Tes digunakan untuk mengukur kemampuan pemecahan masalah matematis yang akan diberikan di akhir penelitian. Soal berbentuk uraian atau essay yang mengacu pada indikator kemampuan pemecahan masalah matematis yang telah diujicobakan. Angket digunakan untuk mengukur keyakinan matematis yang diberikan pada akhir pertemuan yang mengacu pada aspek keyakinan matematis. Didapatkan 28 pernyataan pada angket dan juga telah diujicobakan pada siswa dalam kelas eksperimen. Analisis data dalam penelitian ini menggunakan uji t. Namun, sebelum data dianalisis, terlebih dahulu dilakukan uji prasyarat data yaitu uji normalitas dan uji homogenitas.

\section{HASIL PENELITIAN DAN PEMBAHASAN}

Hasil dari kemampuan pemecahan masalah matematis siswa dan keyakinan matematis siswa yang diperoleh, kemudian dianalisis menggunakan teknik analisis data yaitu dengan uji-t. Tetapi sebelum menggunakan uji-t, data harus dilakukan uji prasyarat yaitu uji normalitas dan uji homogenitas. Jika data sudah berdistribusi normal serta data sudah homogen maka bisa dilakukan ujit. Uji normalitas dalam penelitian ini menggunakan rumus Chi-kuadrat. Hasil uji normalitas data ditunjukkan pada tabel 1 dan 2.

Tabel 1. Hasil Uji Normalitas Kemampuan Pemecahan Masalah Matematis Kelas Eksperimen Dan Kelas Kontrol

\begin{tabular}{cccc}
\hline Kelas & $\boldsymbol{X}_{\text {hitung }}^{\mathbf{2}}$ & $\boldsymbol{X}_{\text {tabel }}^{\mathbf{2}}$ & Kesimpulan \\
\hline Eksperimen & 4,22 & 11,07 & Normal \\
Kontrol & 10,35 & & Normal
\end{tabular}

Tabel 2. Hasil Uji Normalitas Angket Keyakinan Matematis Kelas Eksperimen dan Kelas Kontrol

\begin{tabular}{cccc}
\hline Kelas & $\boldsymbol{X}_{\text {hitung }}^{\mathbf{2}}$ & $\boldsymbol{X}_{\text {tabel }}^{\mathbf{2}}$ & Kesimpulan \\
\hline Eksperimen & 1,80 & 11,07 & Normal \\
Kontrol & 1,98 & & Normal \\
\hline
\end{tabular}


Dari tabel 1 dan tabel 2 terlihat bahwa hasil uji normalitas data kelas eksperimen dan kelas kontrol nilai $\mathrm{X}_{\text {hitung }}^{2}<\mathrm{X}_{\text {tabel }}^{2}$ dengan taraf signifikan $\alpha=$ $5 \%$, maka data berdistribusi normal.

Jika kedua kelompok sampel berdistribusi normal, maka dilanjutkan dengan menguji homogenitas kedua varians. Uji homogenitas juga merupakan salah satu uji prasyarat uji t. Uji homogenitas bertujuan untuk membuktikan persamaan variasi kelompok yang membentuk sampel tersebut dengan syarat pengambilan sampel harus representatif, artinya harus dapat mewakili satu populasi dengan baik Uji homogenitas dalam penelitian ini menggunakan Uji F (Fisher) dengan taraf signifikan $\alpha=5 \%$. Hasil uji homogenitas data ditunjukkan pada tabel 3 dan tabel 4 .

Tabel 3. Hasil Uji Homogenitas Kemampuan Pemecahan Masalah Matematis Kelas Eksperimen Dan Kelas Kontrol

\begin{tabular}{cccc}
\hline Kelas & $\boldsymbol{F}_{\text {hitung }}$ & $\boldsymbol{F}_{\text {tabel }}$ & Kesimpulan \\
\hline Eksperimen & 1,031 & 1,85 & Homogen \\
Kontrol & & & Homogen \\
\hline
\end{tabular}

Tabel 4. Hasil Uji Homogenitas Angket Keyakinan Matematis Kelas Eksperimen dan Kelas Kontrol

\begin{tabular}{cccc}
\hline Kelas & $\boldsymbol{F}_{\text {hitung }}$ & $\boldsymbol{F}_{\text {tabel }}$ & Kesimpulan \\
\hline Eksperimen & 1,03 & 1,85 & Homogen \\
Kontrol & & & Homogen \\
\hline
\end{tabular}

Dari tabel 3 dan tabel 4 terlihat bahwa nilai Fhitung < Ftabel maka dapat disimpulkan bahwa varians data dari kedua sampel, bersifat homogen.

Setelah data memenuhi syarat normal dan homogen maka selanjutnya pengujian hipotesis dilakukan menggunakan uji t. Kriteria pengujian hipotesis dalam penelitian ini adalah $H_{0}$ diterima apabila $\mathrm{t}_{\text {hitung }}<\mathrm{t}_{(1-\alpha)}$ dan tolak $H_{0}$ apabila $t_{\text {hitung }} \geq t_{(1-\alpha)}$ dengan derajat kebebasannya $(d k)=(n 1+n 2-2)$, pada taraf signifikan 5\% (Kesumawati, 2009).

Tabel 5. Hasil Uji Hipotesis 1 Kelas Eksperimen Dan Kelas Kontrol

\begin{tabular}{ccc}
\hline $\boldsymbol{t}_{\text {hitung }}$ & $\boldsymbol{t}_{\text {tabel }}$ & Kesimpulan \\
\hline 2,71 & 1,67 & $H_{0}$ \\
& & Ditolak \\
\hline
\end{tabular}


Berdasarkan tabel 5 hasil uji hipotesis $1 \mathrm{t}$ hitung $=2,71>\mathrm{t}$ tabel $=1,67$ sehingga $\mathrm{H}_{\mathrm{O}}$ ditolak. Jadi disimpulkan “Ada pengaruh yang signifikan model problem based learning terhadap kemampuan pemecahan masalah matematis siswa SMP di kecamatan Gelumbang".

Dari hasil akhir yang dilakukan pada kelas eksperimen dan kelas kontrol, hasil kemampuan pemecahan masalah matematis siswa yang diberi perlakuan dengan menggunakan model problem based learning pada kelas eksperimen memiliki rata-rata skor akhir lebih tinggi dibandingkan kelas kontrol yang diberi perlakuan dengan menggunakan model pembelajaran konvensional. Berdasarkan penelitian relevan yang dilakukan Gunantara et al., (2014) yang menyatakan bahwa model pembelajaran problem based learning lebih efektif dalam meningkatkan kemampuan pemecahan masalah matematis peserta didik.

Begitu juga dengan penelitian yang dilakukan oleh Ayu et al., (2016) yang menyimpulkan bahwa kemampuan pemecahan masalah matematika siswa yang belajar menggunakan model problem based learning berada dalam kualifikasi baik dan model pembelajaran problem based learning memberi pengaruh pada kemampuan pemecahan masalah matematika. Menurut Duch dalam (Shoimin, 2014) problem based learning atau pembelajaran berbasis masalah adalah model pengajaran yang bercirikan adanya permasalahan nyata sebagai konteks untuk para peserta didik belajar berpikir kritis dan keterampilan memecahkan masalah serta memperoleh pengetahuan. Sehingga pada pembelajaran dengan metode problem based learning dapat melatih siswa untuk lebih aktif dalam menyelesaikan suatu masalah dan membuat siswa mampu berusaha memecahkan permasalahan dalam kehidupan sehari-hari.

Pada saat proses pembelajaran siswa diberikan Lembar Kerja Siswa (LKS) dan siswa secara berkelompok berusaha untuk memecahkan masalah yang ada di LKS yang bersangkutan dengan kehidupan dunia nyata. Hal ini menunjukkan bahwa model problem based learning dapat melatih kemampuan pemecahan masalah matematis siswa, pada saat siswa berdiskusi pada masingmasing kelompoknya mereka bertukar pendapat mengenai bagaimana untuk memecahkan masalah. Ketika siswa memahami masalahnya tersebut, selanjutnya siswa menyelesaikan permasalahan yang ada. Dari setiap kelompok mereka mempresentasikan hasil kerjanya di depan kelas, pada kelompok lainnya bebas untuk memberikan tanggapannya selama proses pembelajaran dengan menggunakan problem based learning dan guru berfungsi sebagai fasilitator. Hal ini didukung juga menurut Rusman (2016: 229) 
merumuskan pengertian pembelajaran berbasis masalah yang merupakan terjemahan dari istilah problem based learning merupakan inovasi dalam pembelajaran karena dalam PBM kemampuan berpikir siswa betul-betul dioptimalkan melalui proses kerja kelompok atau tim yang sistematis, sehingga siswa dapat memberdayakan, mengasah, menguji, dan mengembangkan kemampuan berpikirnya secara berkesinambungan.

Pada pembelajaran yang dilakukan pada kelas kontrol yang menggunakan model konvensional, guru menjelaskan materi di depan kelas, tanya jawab, dan latihan soal. Dalam proses pembelajaran dengan model konvensional guru menjelaskan materi dan memberikan waktu kepada siswa untuk bertanya dan mencatat. Selanjutnya guru memberikan contoh soal dan latihan kepada siswa untuk dikerjakan. Kegiatan belajar menggunakan model konvensional, guru lebih mendominasi kegiatan dikelas sehingga siswa menjadi pasif.

Dari hasil analisis tes akhir didapat kemampuan pemecahan masalah matematis siswa pada kelas eksperimen dalam menyelesaikan soal essay sebanyak 4 soal yang diadakan pada pertemuan kelima dengan nilai rata-rata kemampuan pemecahan masalah matematis siswa dengan menggunakan problem based learning adalah 80,99 dan simpangan baku didapat sebesar 13,26. Sedangkan pada kelas kontrol nilai rata-rata kemampuan pemecahan masalah matematis siswa dengan menggunakan model konvensional adalah 72,22 dengan simpangan baku 13,19. Hal ini menunjukkan kemampuan pemecahan masalah matematis siswa dalam menyelesaikan soal matematika pada kelas eksperimen lebih tinggi dari pada kelas kontrol. Perbedaan tersebut disebabkan pada kelas kontrol tidak diberikan perlakuan dengan problem based learning yang sama seperti dikelas eksperimen melainkan diberikan perlakuan dengan model konvensional.

Dari data tersebut menunjukkan bahwa dengan menggunakan model problem based learning hasilnya lebih baik dibandingkan dengan menggunakan model konvensional. Dengan menerapkan model problem based learning siswa dapat menjadi lebih aktif dalam kegiatan belajar karena siswa dapat menemukan sendiri pemecahan masalah mengenai materi yang dipelajari, serta siswa dapat menyelesaikan masalah nyata dan mengaitkan materi yang dipelajari dalam kehidupan sehari-hari sehingga tercipta suasana belajar yang kondusif. Hal ini dapat berpengaruh dengan kemampuan pemecahan masalah matematis siswa. 
Tabel 6. Hasil Uji Hipotesis 2 Kelas Eksperimen dan Kelas Kontrol

\begin{tabular}{ccc}
\hline $\boldsymbol{t}_{\text {hitung }}$ & $\boldsymbol{t}_{\text {tabel }}$ & Kesimpulan \\
\hline 3,56 & 1,67 & $H_{0}$ \\
& & Ditolak \\
\hline
\end{tabular}

Berdasarkan tabel 6 hasil uji hipotesis 2 thitung $=3,56>\mathrm{t}$ tabel $=1,67$ sehingga $\mathrm{H}_{\mathrm{O}}$ ditolak. Jadi disimpulkan "Ada pengaruh yang signifikan model problem based learning terhadap keyakinan matematis siswa SMP di kecamatan Gelumbang".

Hasil angket keyakinan matematis dengan menggunakan model problem based learning lebih tinggi dibandingkan dengan menggunakan model pembelajaran konvensional.

Dari persentase ketercapaian terlihat bahwa perbedaan antara persentase ketercapaian keyakinan matematis siswa pada kelas eksperimen lebih besar dibandingkan persentase ketercapaian keyakinan matematis siswa pada kelas kontrol. Ini menunjukkan bahwa siswa kelas eksperimen yang pembelajarannya menggunakan model problem based learning lebih baik dibandingkan dengan kelas kontrol dengan menggunakan model pembelajaran konvensional.

Menurut Gunantara, Suarjana, \& Riastini (2014), problem based learning adalah metode instruksional yang menantang peserta didik dalam kelompok untuk mencari solusi bagi masalah yang nyata, sehingga dapat menimbulkan rasa keingintahuan peserta didik dalam memecahkan suatu permasalahan yang ada, maka dari hal tersebut dapat memunculkan rasa percaya diri peserta didik, karena peserta didik dapat melihat kemampuan akan dirinya yang dapat menyelesaikan atau mencari solusi dari permasalahan yang ada. Seperti definisi keyakinan matematis adalah kondisi mental yang diakui benar oleh dirinya, meskipun orang lain belum tentu mengakui kebenarannya (Muhtarom, Juniati, \& Siswono, 2016). Hal ini diperkuat berdasarkan penelitian yang dilakukan oleh Dinandar (2014).

Gunantara, Suarjana, \& Riastini (2014) menyimpulkan bahwa kemampuan berpikir kritis dan kreatif matematis yang belajar menggunakan model problem based learning berada dalam kualifikasi baik dan model pembelajaran problem based learning memberi pengaruh pada kemampuan berpikir kritis dan kreatif siswa, sedangkan Ayu, Nurrahmawati, \& Deswita (2016) menyimpulkan bahwa ada pengaruh problem based learning terhadap 
keyakinan matematis siswa dengan kategori tinggi dan problem based learning lebih baik dibandingkan dengan pembelajaran konvensional.

\section{SIMPULAN}

Dari hasil analisis data dan pembahasan, disimpulkan bahwa ada pengaruh model problem based learning terhadap kemampuan pemecahan masalah metematis dan keyakinan matematis siswa SMP di Kecamatan Gelumbang.

\section{DAFTAR PUSTAKA}

Ayu, R., Nurrahmawati, \& Deswita, H. (2016). Pengaruh penerapan model pembelajaran problem based learning (PBL) terhadap kemampuan pemecahan masalah matematika pada siswa kelas VII SMPN 3 Rambah Samo. Jurnal Ilmiah Mahasiswa Matematika, 2(2). Retrieved from https://www.neliti.com/publications/110789/pengaruh-penerapanmodel-pembelajaran-problem-based-learning-pbl-terhadap-kemamp.

Dinandar. (2014). Pengaruh model pembelajaran berbasis masalah (PBM) terhadap kemampuan berpikir kritis matematis siswa di SMK Dharma Karya Jakarta. Universitas Islam Negeri Syarif Hidayatullah Jakarta.

Gunantara, G., Suarjana, I. M., \& Riastini, P. N. (2014). Penerapan model pembelajaran problem based learning untuk meningkatkan kemampuan pemecahan masalah matematika siswa kelas V. Jurnal Mimbar PGSD Universitas Pendidikan Ganesha Jurusan PGSD, 2(1). Retrieved from https:/ / ejournal.undiksha.ac.id/index.php/JJPGSD/article/view/2058

Kesumawati. (2009). Peningkatan kemampuan pemecahan masalah matematis siswa SMP melalui model pendidikan matematika realistik. Universitas PGRI Palembang. Retrieved from http://repository.upi.edu/7975/.

Muhtarom, Juniati, D., \& Siswono, T. Y. E. (2016). Pengembangan angket keyakinan dalam pemecahan masalah dan pembelajaran matematika. Jurnal Ilmiah Pendidikan Matematika, 2(1), 55-64. Retrieved from https:/ / media.neliti.com/media/publications/91434-IDpengembangan-angket-keyakinan-terhadap-p.pdf.

Rusman. (2016). Model-model pembelajaran: Mengembangkan profesionalisme guru. Jakarta: PT RajaGrafindo Persada.

Sari, S. (2014). Pengaruh model pembelajaran berbasis masalah terhadap kemampuan pemecahan masalah matematika siswa kelas VIII SMP Negeri 1 Padang Tahun Pelajaran 2013/2014. Jurnal Penelitian Pendidikan Matematika, 3(2). Retrieved from http:/ / ejournal.unp.ac.id/students/index.php/pmat/index.

Shadiq, F. (2009). Kemahiran matematika. Yogyakarta: Pusat Perbukuan Departemen Pendidikan Nasional. 
Shoimin, A. (2014). Model pembelajaran inovatif dalam kurikulum 2013. Yogyakarta: Ar-ruzz Media.

Sugiman. (2009). Aspek keyakinan matematik siswa dalam pendidikan matematika. Jurnal Pendidikan MIPA UNY, 2(1). Retrieved from http://staff.uny.ac.id/sites/default/files/131930135/2009b_KYM_0.pd $\mathrm{f}$.

Sugiman. (2010). Peningkatan keyakinan matematik melalui pembelajaran matematika realistik. Jurnal Pendidikan MIPA UNY. Jurnal Pendidikan MIPA UNY, 2(1). Retrieved from http://staff.uny.ac.id/sites/default/files/131930135/2010b_Keyakinan _Mat.pdf.

Sundayana, R. (2015). Media dan alat peraga dalam pembelajaran matematika. Bandung: Alfabeta.

Suyadi. (2015). Strategi pembelajaran pendidikan karakter. Bandung: PT Remaja Rosdakarya.

Tim Depdiknas. (2006). Peraturan pemerintah republik indonesia nomor 22 tahun 2006 tentang standar isi untuk satuan pendidikan dasar dan menengah.

Widjajanti, D. (2009). Mengembangkan keyakinana (belief) siswa terhadap matematika melalui pembelajaran berbasis masalah. Yohyakarta. Retrieved from http://staff.uny.ac.id/sites/default/files/131569335/Makalah Medan2.pdf.

Yulianti, E., Sukasno, \& Friansah, D. (2016). Pengaruh model problem based learning (pbl) terhadap kemampuan pemecahan masalah matematis siswa kelas X SMA Negeri 2 Lubuk Linggau. Retrieved from http://mahasiswa.mipastkipllg.com/repository/Artikel Evimaz Yulianti.pdf. 